\title{
CORPORATE TAX POLICY AND INTERNATIONAL MERGERS AND ACQUISITIONS - IS THE TAX EXEMPTION SYSTEM SUPERIOR?
}

\author{
JOHANNES BECKER \\ Clemens Fuest
}

CESIFO WORKING PAPER NO. 1884

CATEGORY 1: PUBLIC FINANCE

JANUARY 2007

An electronic version of the paper may be downloaded

- from the SSRN website:

- from the RePEc website:

www.SSRN.com

- from the CESifo website:

www.RePEc.org

www.CESifo-group.de 


\title{
CORPORATE TAX POLICY AND INTERNATIONAL MERGERS AND ACQUISITIONS - IS THE TAX EXEMPTION SYSTEM SUPERIOR?
}

\begin{abstract}
In this paper we ask whether recent claims that the US government should switch from the tax credit system to the exemption system are justified. We study corporate taxation in a model where international capital flows are either greenfield investment projects or acquisitions of existing firms, and where investment is motivated by either cost reduction or market entry reasons. The paper asks how corporate taxation affects the international allocation of capital under different double taxation regimes. We find that the standard view on international taxation only prevails in the case of cost driven greenfield investment. In all other cases the deduction system is no longer optimal from a national perspective and the foreign tax credit system fails to ensure neutrality. However, the desirability of the tax exemption system has to be qualified. We show that the cross border cash flow tax system dominates the exemption system in terms of optimality properties.
\end{abstract}

JEL Code: H25, F23.

Keywords: corporate taxation, international capital flows.

Johannes Becker

Cologne Center for Public Economics

University of Cologne

Albertus-Magnus-Platz

50923 Cologne

Germany

johannes.becker@uni-koeln.de
Clemens Fuest

Cologne Center for Public Economics

University of Cologne

Albertus-Magnus-Platz

50923 Cologne

Germany

clemens.fuest@uni-koeln.de

This version: December 2006

We thank Kai Konrad, Ray Rees and participants at research workshops in Berlin and Munich for very helpful comments. We gratefully acknowledge financial support from the Deutsche Forschungsgemeinschaft (DFG), Grant No. FU 442/3-1. 


\section{Introduction}

Recent tax policy contributions claim that the US government should abandon the tax credit system for the taxation of foreign profits and switch to the exemption system (Desai \& Hines $(2003,2004)$ ). The authors point out that the tax credit system is appropriate in a world where foreign investment reduces the domestic capital stock. In such a setting, which is often related to the notion of greenfield investment, firms decide whether to set up new production facilities at home or abroad, or even relocate existing plants to the foreign country. But empirically, a large part of US foreign investment occurs in the form of mergers and acquisitions (m\&a). Foreign investment then leads to a change in the ownership of existing production facilities, rather than a relocation of economic activity. ${ }^{1}$ Desai and Hines (2004) argue that the current U.S. taxation of foreign profits creates an undesirable disadvantage for American firms trying to acquire foreign firms and conclude: "efficiency requires that foreign investment income face no residual tax upon repatriation" (p. 938).

From an analytical point of view, the point made by Desai and Hines has two conceptual dimensions. The first dimension is the difference between greenfield investment, i.e. creating new production facilities, and m\&a transactions, i.e. purchasing existing production facilities. The second dimension is the difference between a setting in which investment abroad decreases investment at home and a world in which these two investment levels are not linked at all. The assumption of mutually exclusive investment projects is appropriate when e.g. outsourcing is analyzed, i.e. a relocation of existing production facilities to benefit from lower production costs abroad. In the following, we will refer to this type of investment as cost driven investment. In contrast, assuming mutually independent investment projects is adequate when foreign investment increases the firm's overall capital stock. This is typically the case for investment projects which provide access to a new market. We will therefore refer to this second type of investment as market

\footnotetext{
${ }^{1}$ As Desai \& Hines (2004) put it, "a very high fraction of such investment takes the form of acquiring existing businesses. Consequently, most FDI represents transfers of control and ownership, and need not involve transfers of net savings. (...) The modern view of FDI as arising from productivity differences among firms, with ownership changes taking the form of FDI, raises the possibility that greater outbound FDI need not be associated with reduced domestic investment." (p. 956)
} 
entry investment. ${ }^{2}$

In the argument made by Desai and Hines, m\&a are related to the concept where foreign investment does not reduce domestic investment. This may be appropriate in many cases. But in general it is not clear, that a foreign acquisition leaves domestic activity of a firm unaffected. Likewise, greenfield investment abroad may have no impact on domestic investment of a multinational firm. If the investment provides access to a new market, it may even increase domestic activity.

From an analytical point of view, it is desirable to treat these two dimensions, greenfield vs. m\&a investment and cost driven vs. market entry investment, separately. Table 1 illustrates this further. The argument provided by Desai \& Hines $(2003,2004)$ builds on two crucial differences to the standard model which is usually associated with the seminal paper by Feldstein \& Hartman (1979). ${ }^{3}$ A priori, it is not clear which of the two changes in the model setup changes the optimal tax reasoning.

\begin{tabular}{c|c|c} 
& \multicolumn{1}{|c}{ Greenfield } & \multicolumn{1}{c}{ M\&A } \\
\hline Cost driven & $\begin{array}{c}\text { Feldstein \& } \\
\text { Hartman (1979) }\end{array}$ & \\
\cline { 2 - 3 } Market entry & & $\begin{array}{c}\text { Desai \& Hines } \\
(2003,2004)\end{array}$
\end{tabular}

Table 1: Concepts of optimal taxation issues

In this paper we offer a framework which treats both conceptual dimensions independently. We analyze the effects of different tax regimes on international investment and derive optimal tax policy strategies both from the national and the

\footnotetext{
${ }^{2}$ In the international economics literature, these two types of foreign direct investment are alternatively labeled vertical (cost driven) and horizontal investment (market entry, see Markusen (2002)). We are aware that this terminology may be controversial. Cost driven foreign investment may also have positive effects on domestic activities of a firm, so that, after all, the domestic and foreign investment may again be complementary to some extent. Equivalently, market entry investment abroad may of course affect domestic investment e.g. by increasing demand for the firm's products. These labels just serve to illustrate the conceptual difference between the two types of investment decisions, further discussed in section 2.

${ }^{3}$ Other standard references are Musgrave (1969), Bond \& Samuelson (1989), Bucovetsky \& Wilson (1991).
} 
global perspective. Our main interest is to find out if the basic results and policy recommendations generated by the standard capital mobility model carry over to different settings with market entry investment instead of cost-driven investment, and m\&a rather than greenfield investment. These results include the ability of the foreign tax credit system to implement neutrality of taxes for the location of investment (Musgrave (1969)) and the national optimality of the deduction system (Feldstein \& Hartman (1979)).

Our findings suggest that the standard results on the optimal taxation of foreign profits are based on a concept of international investment which is too narrow. Firstly, we find that it is not optimal for an individual country to tax foreign source income according to the full taxation after deduction system (Feldstein \& Hartman (1979)), except for the case of cost driven greenfield investment. Secondly, the foreign tax credit system fails to achieve globally optimal capital flows in all cases except for cost driven greenfield investment. In the case of m\&a investment, this happens because an acquisition implies the transfer of an asset which produces taxable income between two owners which may be taxed differently. If the income of the acquiring firm is taxed more heavily than the income of the seller, acquisitions are distorted. Thirdly, the exemption regime, which generates overinvestment in the low tax country in the case of cost driven greenfield investment, is superior in terms of both national and global welfare for both types of market entry investment. But for cost driven m\&a transactions, the exemption system again leads to overinvestment in the low tax country, and national and global welfare maximization requires a cross border cash flow tax regime.

These findings do not only challenge standard results of international tax theory. They also have important policy implications. Firstly, they confirm that the exemption system is superior to the tax credit system from a national perspective if foreign investment in the form of m\&a plays an important role and some additional conditions are met. This also implies that some European countries like Germany which are considering to give up their exemption systems may neglect important costs of such a move. Secondly, our results are relevant for the ongoing debate on corporate tax coordination in the European Union. Differences in source based corporate income taxes are often seen as a major source of investment distortions in the European internal market. Our analysis suggests that a move towards more 
residence based taxation through the use of tax credit systems may introduce new distortions, distortions of corporate ownership structures, which may not be less harmful.

The remainder of the paper is set up as follows. In section 2, we discuss some conceptual issues and briefly review the related literature. Section 3 presents the model and the results. Section 4 discusses some extensions. In section 5, we discuss some theoretical and empirical implications of our results and conclude.

\section{Conceptual issues, definitions and related lit- erature}

In this section, we provide the conceptual basis for the model analysis in section 3 . We explain the difference between greenfield investment and m\&a in our theoretical approach (2.1), we deal with the distinction between cost driven and market entry investment (2.2), and we briefly discuss optimality criteria for international tax regimes (section 2.3 ).

\subsection{Mergers and acquisitions versus greenfield investment}

As recent surveys on the impact of taxes on cross-border capital flows, like Devereux (2006) and Hines (1999), show, virtually all studies treat investment flows as if they were greenfield projects. But, capital flows in the form of border crossing m\&a are empirically important. Table 1 shows the FDI outflows from different regions and countries into the rest of the world in 2004 (column 2). ${ }^{4}$ Columns 3 and 4 report m\&a purchases in absolute value and, in italics, as a fraction of overall net FDI outflows. For example, in 2004, US firms purchased other firms abroad for the amount of 110 billion dollars; this was $48 \%$ of net FDI outflows of the US economy.

\footnotetext{
${ }^{4}$ Note that these are net outflows, which are calculated as investment minus disinvestment.
} 
Table 1: FDI outflows and M\&A purchases abroad of different regions and countries in millions of dollars.

\begin{tabular}{lrrrr}
\hline & FDI outflows & & \multicolumn{2}{c}{ M\&A Purchases } \\
\cline { 2 - 3 } \cline { 5 - 5 } Region/economy & $\mathbf{2 0 0 4}$ & & $\mathbf{2 0 0 4}$ \\
\hline World & 730,257 & & 380,598 & $52.1 \%$ \\
Developed economies & 637,360 & & 339,799 & $53.3 \%$ \\
European Union & 279,830 & 164,677 & $58.8 \%$ \\
United States & 229,294 & 110,022 & $48.0 \%$ \\
Japan & 30,951 & 3,787 & $12.2 \%$ \\
Developing Economies & 83,190 & 39,809 & $47.9 \%$ \\
\hline
\end{tabular}

Notes: UNCTAD data, World Investment Report 2005. FDI outflows are net flows, i.e. investment minus divestment, from the reporting country or region (column 1 ) into the rest of the world. FDI outflows indicate disinvestment. M\&A purchases are the value of purchased firms abroad.

What are the key differences between greenfield investment and m\&a from a tax policy perspective? In this paper, we use the following simple

\section{Definition 1}

Greenfield investment is the purchase of internationally mobile capital goods and the choice of a location for production.

MEa investment is the purchase of an existing and immobile production facility.

In the literature, the tax policy implications of capital flows in the form of $m \& a$ have been neglected almost completely. An exception is a contribution by Devereux (1990), who does not refer explicitly to mergers and acquisitons but points out that tax distortions of ownership patterns may be important if capital productivity depends on ownership. The paper introduces the concept of "capital ownership neutrality" as a property of tax systems which avoid distortions in ownership. ${ }^{5}$ Moreover, there are the two papers mentioned above, Desai \& Hines (2003) and Desai \& Hines (2004), which do not include a formal model though, and focus on U.S. tax policy. ${ }^{6}$

\footnotetext{
${ }^{5}$ Gordon \& Bovenberg (1996) consider cross border acquisitions in a model with asymmetric information in order to explain the correlation between savings and investment reported by Feldstein \& Horioka (1980). Fuest \& Huber (2004) analyze tax policy in a model where firms may be sold to foreign investors, but they focus on the integration of personal and corporate income taxes, and no border crossing acquisitions take place in equilibrium.

${ }^{6}$ See also the debate between Grubert (2005) and Desai \& Hines (2005).
} 
Mergers and acquisitions play an important role in the literature on multinational firms and their investment behavior (including both types of investment, greenfield investment and m\&a), surveyed by Markusen (2002). ${ }^{7}$ Empirical evidence on m\&a is reported by Andrade, Mitchell \& Stafford (2001) and others. ${ }^{8}$

How does taxation affect m\&a activity? As Auerbach \& Slemrod (1997) and Kaplan (1989) suggest, taxes may be of crucial importance for m\&a investment. There are some papers discussing the impact of the 1986 U.S. tax reform on acquisitions of US firms by foreign investors. Here, the main idea is that the effective increase in the tax burden caused by the 1986 tax reform induced investors located in countries with foreign tax credit regimes to take over U.S. firms because the higher US taxes were credited against home country taxes (Scholes \& Wolfson (1990), Collins, Kemsley \& Shackelford (1995)). Swenson (1994) applies the same argument to US inbound foreign direct investment and finds robust evidence supporting the hypothesis. In a recent paper, Huizinga \& Voget (2005) study the empirical impact of international taxation schemes on m\&a activity. The authors find robust and significant evidence for the deterring impact of double taxation on cross-border acquisitions.

\subsection{Cost driven versus market entry investment}

The question of how foreign investment affects domestic investment is an important issue for international tax policy. In the seminal paper by Feldstein \& Hartman (1979), the capital stock is of fixed size. This implies that each unit of capital invested abroad reduces the capital stock at home by one unit. In contrast, in a widely cited paper on the taxation of border crossing investment, Mintz \& Tulkens (1996) consider a model where multinational firms may invest in two countries which face a perfectly elastic supply of capital, so that a change in foreign investment does not affect domestic investment.

In this paper, we take into account both cases, mutually exclusive and mutually independent investment. In order to distinguish these two types of investment, we

\footnotetext{
${ }^{7}$ There are also some recent theoretical papers on merger policy (Haufler \& Nielsen (2005)) as well as on m\&a and trade policy (Huck \& Konrad (2004)).

${ }^{8}$ These include Schoar (2002), McGuckin \& Nguyen (1995), Rossi \& Volpin (2004) and Di Giovanni (2005).
} 
introduce the labels of cost driven investment and market entry investment. ${ }^{9}$ In the case of cost driven investment, a firm invests abroad rather than at home to benefit from lower prices for factors of production which are available at the foreign location. In this case, the alternative to foreign investment is domestic investment. Therefore, more foreign investment implies less domestic investment. Things are different in the case of market entry investment. In this case, an investment project may or may not be profitable, but at least at the firm level, the alternative to investing in a given country is not to invest at all, rather than investing in another country. We therefore introduce

\section{Definition 2}

Cost driven investment projects are mutually exclusive. The project is realized either in the domestic or in the foreign country. Investment abroad reduces investment at home.

Market entry investment projects are carried out as long as the project return is non-negative. Investment abroad does not affect domestic investment.

A priori, there is no reason to assume that cost driven investment is linked to greenfield investment, and market entry investment to m\&a transactions, or vice versa. Therefore, we consider all four cases: greenfield with cost and market entry motives, and m\&a with cost and market entry motives.

\subsection{Optimal tax policy and regimes of international taxa- tion}

Starting with Feldstein \& Hartman (1979), a broad literature evolved on the question of how to optimally tax foreign source income. Horst (1980), as well as Keen \& Piekkola (1997) relax the assumption of a fixed capital stock and consider the effect of taxes on savings. Grubert \& Mutti (1995) consider two specific cases of investment, portfolio investment on the one hand and $R \& D$ investment on the

\footnotetext{
${ }^{9}$ These are just labels which serve to illustrate an analytical distinction. Another frequently used terminology is the distinction between horizontal and vertical investment, for a discussion see e.g. Markusen (2002), p.5.
} 
other hand. However, the standard results derived by Feldstein and Hartman prevail. Janeba (1995) and Mintz \& Tulkens (1996) analyze the desirability and the effects of double taxation agreements. ${ }^{10}$ Devereux \& Hubbard (2003) derive welfare effects of taxes on foreign source income of multinational enterprises.

For the following analysis, it is useful to introduce two optimality criteria:

\section{Definition 3}

National optimality (NO) prevails if investment decisions cannot be changed without reducing national income.

Global optimality (GO) prevails if investment decisions cannot be changed without reducing global income.

The standard view derived in the Feldstein-Hartman model is that NO is satisfied by a tax system which fully taxes foreign source income after deducting foreign taxes. GO is given if foreign taxes are credited against domestic taxes. In the following section, we ask whether these results carry over to a framework which distinguishes cost driven vs. market entry and greenfield vs. m\&a investment.

\section{A model of international capital flows with taxes}

There are two locations for investment, the domestic country and the foreign country. In the domestic country, there are many firms investing domestically and abroad owned by a representative domestic household. We refer to these firms as investor firms. For notational convenience, we normalize their number to unity.

In the following, we firstly analyze greenfield investment as a reference case before we focus on m\&a investment.

\subsection{Greenfield investment}

The representative investor firm purchases capital goods at a price denoted by $p$. These goods are internationally tradeable and they are supplied by a capital goods

\footnotetext{
${ }^{10}$ Further contributions are surveyed in Fuest, Huber \& Mintz (2005).
} 
industry located in the domestic country. This industry has constant average and marginal costs equal to $p$. This implies that the supply of capital is perfectly elastic. $^{11}$

Each greenfield investment project requires one unit of capital. As indicated in section 2, it is important whether i) investment abroad implies that an equivalent investment at home cannot take place (cost driven investment) or ii) investment abroad simply increases the capital stock of the domestic investor firm (market entry investment). We will discuss both cases in turn.

\subsubsection{Cost driven greenfield investment}

The representative investor firm considers realizing a greenfield project in its home country or abroad. The return of project $j$ is denoted $\Delta_{c j}$ if located in the domestic country and $\Delta_{c j}^{*}$ if located abroad. The subscript $c$ stands for 'cost driven'. The investor firm draws a pair $\left(\Delta_{c j}, \Delta_{c j}^{*}\right)$ of two jointly distributed variables $\left(\Delta_{c}, \Delta_{c}^{*}\right) \in \mathbb{R}^{2}$ with the density function $\vartheta\left(\Delta_{c}, \Delta_{c}^{*}\right)$ and the distribution function $\Theta\left(\Delta_{c}, \Delta_{c}^{*}\right)$. We assume that after-tax profits are always strictly non-negative in both locations. ${ }^{12}$ For a given domestic profit $\Delta_{c}$, the firm will choose the foreign location for all projects with a return above a critical value $\Delta_{c}^{* m}$, which is given by

$$
\Delta_{c}^{* m}\left(1-\tau^{*}\right)-T\left(\Delta_{c}^{* m}\right)-p=\Delta_{c}(1-\tau)-p
$$

where $\tau\left(\tau^{*}\right)$ is the domestic (foreign) corporate income tax rate and $T\left(\Delta_{c}^{* m}\right)$ is the repatriation tax, i.e. the domestic tax on foreign profits. ${ }^{13}$

Figure 1 illustrates the model. All projects are located in the $\left(\Delta_{c}, \Delta_{c}^{*}\right)$ space. In the absence of taxes, equation (1) becomes $\Delta_{c}=\Delta_{c}^{* m}$. The 45 degree line in figure 1 illustrates locational indifference in this case. All projects above this line

\footnotetext{
${ }^{11}$ The assumption of an elastic capital supply follows Mintz and Tulkens (1996) and constitutes an important difference to the Feldstein-Hartman model. In section 4, we consider the case of a fixed capital stock.

${ }^{12}$ We abstract from the possibility that either domestic or foreign investment yields a negative profit because this would take us to a setting where investors choose between investing in one of the two countries and not investing. This case is analysed below, under the heading 'market entry investment'.

${ }^{13}$ We assume that the distribution of profits across jurisdictions is given. We thus abstract from the possibility of shifting profits across countries via debt or transfer pricing.
} 
will be located in the domestic country and all projects below the line will be located abroad.

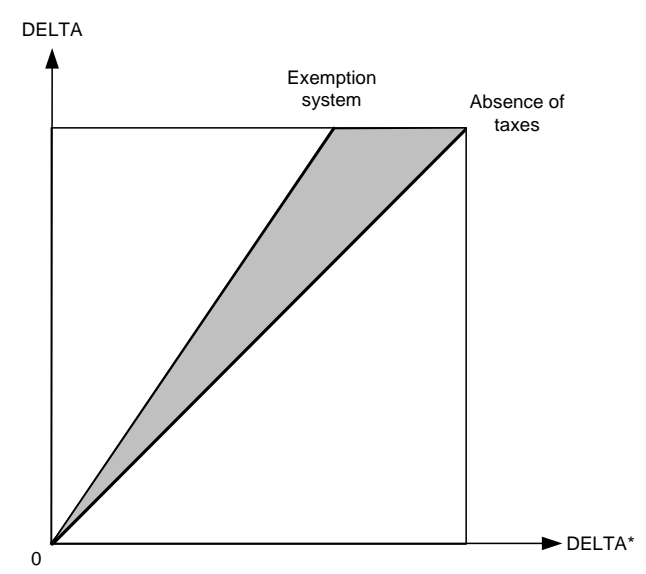

Figure 1: Cost driven greenfield investment

In the presence of taxes, the locational indifference line may shift. In figure 1 , the graph shows the case where foreign profits are exempt from domestic taxes $\left(T\left(\Delta_{c}^{* m}\right)=0\right)$, which implies $\Delta_{c}=\Delta_{c}^{* m}\left(\frac{1-\tau^{*}}{1-\tau}\right)$, and the domestic country is the high tax country $\left(\tau>\tau^{*}\right)$. In the shaded area, all projects are realized in the foreign country. In the absence of taxes, they would have been located in the domestic country.

In this paper, we will consider four different regimes for taxing foreign profits. These are

1. The exemption system: $T\left(\Delta_{c}^{*}\right)=0$.

2. The full taxation after deduction system: $T\left(\Delta_{c}^{*}\right)=\tau\left(1-\tau^{*}\right) \Delta_{c}^{*}$.

3. The foreign tax credit system: $T\left(\Delta_{c}^{*}\right)=\left(\tau-\tau^{*}\right) \Delta_{c}^{*}$

4. The cross border cash flow tax system: $T\left(\Delta_{c}^{*}\right)=\tau\left[\left(1-\tau^{*}\right) \Delta_{c}^{*}-p\right]$.

What are the implications of corporate taxation for national and global welfare? National income from domestic and foreign investment is given by domestic profits before taxes plus foreign profits after foreign taxes, i.e.

$$
W^{n}=\int_{-\infty}^{\infty}\left[\int_{-\infty}^{\Delta_{c}^{* m}}\left[\Delta_{c}-p\right] \vartheta^{c} d \Delta_{c}^{*}+\int_{\Delta_{c}^{* m}}^{\infty}\left[\Delta_{c}^{*}\left(1-\tau^{*}\right)-p\right] \vartheta_{\Delta}^{c} d \Delta_{c}^{*}\right] d \Delta_{c}
$$

with $\vartheta_{\Delta}^{c}=\vartheta\left(\Delta_{c}, \Delta_{c}^{*}\right)$ for notational simplicity. The effect of a change in the 
cutoff value $\Delta_{c}^{* m}$ on domestic welfare is

$$
\frac{W^{n}}{\partial \Delta_{c}^{* m}}=\int_{-\infty}^{\infty}\left[\Delta_{c}-\Delta_{c}^{* m}\left(1-\tau^{*}\right)\right] \vartheta\left(\Delta_{c}, \Delta_{c}^{* m}\right) d \Delta_{c}
$$

This implies that national optimality requires all investment projects to be located abroad if, for a given $\Delta_{c}, \Delta_{c j}^{*} \geq \Delta_{c}^{* N O}$, where $\Delta_{c}^{* N O}$ is given by:

$$
\mathrm{NO}_{c}: \quad \Delta_{c}^{* N O}\left(1-\tau^{*}\right)=\Delta_{c}
$$

Global income includes foreign and domestic profits before taxes. Therefore, globally optimal investment requires

$$
\mathrm{GO}_{c}: \quad \Delta_{c}^{* G O}=\Delta_{c}
$$

Which regimes for taxing foreign profits lead to national and global optimality? Comparing (1) and (4) shows that nationally optimal investment is achieved if $T\left(\Delta_{c}^{*}\right)=\tau\left(1-\tau^{*}\right) \Delta_{c}^{*}$, i.e. foreign profits are taxed according to the full taxation after deduction system (Feldstein \& Hartman (1979)). Global optimality requires $T\left(\Delta_{c}^{*}\right)=\left(\tau-\tau^{*}\right) \Delta_{c}^{*}$, i.e. taxation according to the foreign tax credit system. We may summarize these findings as

Proposition 1 In the case of cost driven greenfield investment, the full taxation after deduction system is nationally optimal. The tax credit system is globally optimal.

These results are of key importance in the theory of international taxation. For the following analysis, they will serve as a benchmark.

\subsubsection{Market entry greenfield investment}

Consider now the case of market entry investment. The idea is that the representative domestic investor firm considers whether or not to carry out a greenfield investment project in the foreign country. Again, each project requires one unit of capital which is available at a price of $p$. The return of project $j$ is now denoted by $\Delta_{e j}^{*}$, where the subscript $e$ stands for 'entry'. For each project, the representative 
investor firm draws a return $\Delta_{e j}^{*}$ of a variable $\Delta_{e}^{*} \in \mathbb{R}$ with density $\vartheta\left(\Delta_{e}^{*}\right)$ and distribution $\Theta\left(\Delta_{e}^{*}\right)$. Firms will carry out all projects in the foreign country with returns $\Delta_{e j}^{*} \geq \Delta_{e}^{m *}$, where the cutoff value $\Delta_{e}^{m *}$ is given by

$$
\Delta_{e}^{m *}\left(1-\tau^{*}\right)-T\left(\Delta_{e}^{m *}\right)-p=0
$$

National income increases with every project where the return after foreign taxes exceeds the investment cost $p$. Nationally optimal investment in the foreign country is therefore given by

$$
\mathrm{NO}_{e}: \quad \Delta_{e}^{N O *}\left(1-\tau^{*}\right)=p
$$

Comparing (6) and (7) shows that the nationally optimal tax on the marginal foreign investment project is equal to zero, $T\left(\Delta_{e}^{m *}\right)=0$. There are two ways of implementing this. The first is to exempt foreign income from domestic taxation. The second is to tax foreign profits according to the cross border cash flow tax system, where $T\left(\Delta_{e}^{*}\right)=\tau\left[\Delta_{e}^{*}\left(1-\tau^{*}\right)-p\right]$, which also leads to $\Delta_{e}^{m *}\left(1-\tau^{*}\right)-p=0$.

How about global optimality? Given that the price of capital is constant, global optimality requires that all investment projects are carried out where the return before taxes exceeds the price per unit of capital. The globally optimal cutoff value for investment in the foreign country is:

$$
\mathrm{GO}_{e}: \quad \Delta_{e}^{G O *}=p
$$

None of the four tax regimes considered here can assure global optimality in this case. The reason is that national tax systems do not allow for a deduction of the costs of capital and therefore distort domestic investment. The best that can be done from a global point of view is to set $T\left(\Delta_{e}^{m *}\right)=0$ by using either the exemption system or the cross border cash flow system.

This may be summarized as

Proposition 2 In the case of market entry greenfield investment, the exemption system and the cross border cash flow systems are nationally optimal. Neither of the four tax regimes under consideration achieves global optimality. 
Proposition 2 shows that the national optimality of the full taxation after deduction system may even vanish in the case of greenfield investment, provided that this investment does not reduce domestic investment. However, this finding critically depends on the assumption of an elastic supply of capital. In section 4, we will consider the case where the global supply of capital is inelastic. In such a setting, foreign market entry greenfield investment crowds out domestic investment, and the national optimality of the full taxation after deduction system and the global optimality of the tax credit system are restored under certain conditions.

\subsection{Mergers and acquisitions}

The model used in the preceding section is modified as follows. The domestic representative investor firm now only undertakes investment projects in the form of acquisitions. Next to the investor firm, there are $N\left(N^{*}\right)$ existing firms in the domestic (foreign) country. We refer to these firms as target firms. Initially, domestic (foreign) target firms are owned by the domestic (foreign) representative household. Under their initial owners, domestic (foreign) target firms earn a uniform pre-tax profit $\pi\left(\pi^{*}\right)$.

An important question arising at this point is whether acquisitions have real economic effects. We assume that this is the case. If a target firm is acquired by the investor firm, the target firm's pre-tax profits change, and we denote this profit change by the variable $\delta$. Target firms are immobile, i.e. the cost of transferring their assets to another country is prohibitively large. This immobility implies that the market price of target firms may differ across countries, even if these firms are identical in all other respects. The price the investor firm pays for a domestic (foreign) target firm is denoted by $q\left(q^{*}\right)$. Again, we distinguish between cost driven investment and market entry investment.

\subsubsection{Cost driven m\&a investment}

The investor firm faces a large number of potential acquisition projects. The profit change achieved by project $j$ is assumed to be $\delta_{c j}$ if the acquisition is made in the domestic country and $\delta_{c j}^{*}$ if the acquisition is made abroad. For each project, the representative investor firm draws a pair $\left(\delta_{c j}, \delta_{c j}^{*}\right)$ of two jointly distributed 
variables $\left(\delta_{c}, \delta_{c}^{*}\right) \in \mathbb{R}^{2}$ with density $\vartheta\left(\delta_{c}, \delta_{c}^{*}\right)$ and distribution $\Theta\left(\delta_{c}, \delta_{c}^{*}\right)$. We assume that the number of target firms in each country exceeds the overall number of acquisition projects. ${ }^{14}$ For a given domestic profit change $\delta_{c}$, the firm will choose the foreign location for all projects with $\delta_{c}^{*} \geq \delta_{c}^{* m}$, where $\delta_{c}^{* m}$ is given by

$$
\left(\pi^{*}+\delta_{c}^{* m}\right)\left(1-\tau^{*}\right)-T\left(\pi^{*}+\delta_{c}^{* m}\right)-q^{*}=\left(\pi+\delta_{c}\right)(1-\tau)-q
$$

The market for target firms is assumed to be perfectly competitive, so that the initial owners receive their reservation income, i.e. $q=\pi(1-\tau)$ and $q^{*}=$ $\pi^{*}\left(1-\tau^{*}\right) \cdot{ }^{15}$ Given this, (9) boils down to

$$
\delta_{c}^{* m}\left(1-\tau^{*}\right)-T\left(\pi^{*}+\delta_{c}^{* m}\right)=\delta_{c}(1-\tau)
$$

What are the implications of taxes for the national and global optimality of private investment decisions? National income from domestic and foreign investment is given by domestic profits before taxes plus foreign profits after foreign taxes, i.e.

$$
W^{n}=\int_{-\infty}^{\infty}\left[\int_{-\infty}^{\delta_{c}^{* m}} \delta \vartheta_{\delta}^{c} d \delta_{c}^{*}+\int_{\delta_{c}^{* m}}^{\infty}\left[\left(\pi^{*}+\delta_{c}^{*}\right)\left(1-\tau^{*}\right)-q^{*}\right] \vartheta_{\delta}^{c} d \delta_{c}^{*}\right] d \delta_{c}
$$

with $\vartheta_{\delta}^{c}=\vartheta\left(\delta_{c}, \delta_{c}^{*}\right)$. Using $q^{*}=\pi^{*}\left(1-\tau^{*}\right)$, the effect of a change in the cutoff value $\delta_{c}^{* m}$ on domestic welfare can be expressed as

$$
\frac{W^{n}}{\partial \delta_{c}^{* m}}=\int_{-\infty}^{\infty}\left[\delta_{c}^{m}-\delta_{c}^{*}\left(1-\tau^{*}\right)\right] \vartheta\left(\delta_{c}^{m}, \delta_{c}^{*}\right) d \delta_{c}
$$

This implies that national optimality requires all investment projects to be located abroad if, for a given $\delta_{c}, \delta_{c j}^{*} \geq \delta_{c}^{* N O}$, where $\delta_{c}^{* N O}$ is given by:

$$
\mathrm{NO}_{c}: \quad \delta_{c}^{* N O}\left(1-\tau^{*}\right)=\delta_{c}
$$

\footnotetext{
${ }^{14}$ If this assumption is relaxed so that equilibria may arise where the the investor firm acquires all firms in at least one country, taxes cease to affect capital flows. This case is neither realistic nor interesting.

${ }^{15}$ In section 4.2 ., we consider the case where the purchase price is determined by bargaining and initial owners receive part of the surplus.
} 
Global income includes foreign and domestic profits before taxes. Therefore, globally optimal investment requires

$$
\mathrm{GO}_{c}: \quad \delta_{c}^{* G O}=\delta_{c}
$$

Which regimes for the taxation of foreign profits lead to national and global optimality? In the case of cost driven greenfield investment, the deduction system is optimal. Here, applying the deduction system, $T\left(\pi^{*}+\delta_{c}^{*}\right)=\tau\left(\pi^{*}+\delta_{c}^{*}\right)\left(1-\tau^{*}\right)$ in (10), would imply:

$$
\delta_{c}^{m *}\left(1-\tau^{*}\right)=\delta_{c}+\tau \frac{\left(1-\tau^{*}\right)}{(1-\tau)} \pi^{*} \Leftrightarrow \quad \delta_{c}^{m *}>\delta_{c}^{* N O}
$$

Equation (15) shows that the deduction system does not lead to nationally optimal investment. The return of the marginal foreign project is too high, which means that too few foreign acquisitions take place. The reason is that, under the deduction system, the repatriation tax gives rise to an extra tax on the acquisition. It changes the tax burden on the "unchanged" part of the income from $\tau^{*} \pi^{*}$ under the initial owner to $\left[\tau^{*}+\tau\left(1-\tau^{*}\right)\right] \pi^{*}$ under the new owner. Imposing this extra burden on foreign acquisitions is not in the interest of national income maximization.

If the full taxation after deduction system does not lead to national optimality, which regime does? Using (10) and (13) reveals that national income maximization requires the application of the cross border cash flow tax system, i.e. $T\left(\pi^{*}+\delta_{c}^{*}\right)=$ $\tau\left(\left(\pi^{*}+\delta_{c}^{*}\right)\left(1-\tau^{*}\right)-q^{*}\right)$. This regime makes sure that the repatriation tax on profits capitalized in the purchase price is equal to zero. As a result, only the additional income generated by the acquisition is affected by the repatriation tax.

How do the exemption system and the tax credit system perform with respect to national optimality? Under the exemption system, $T\left(\pi^{*}+\delta_{c}^{*}\right)=0$ and (10) can be rearranged to

$$
\delta_{c}^{* m}\left(1-\tau^{*}\right)=\delta_{c}(1-\tau) \quad \Leftrightarrow \quad \delta_{c}^{* m}<\delta_{c}^{* N O}
$$

It turns out that there are more foreign acquisitions (and less domestic acquis- 
itions) than nationally optimal. Finally, under the tax credit system the repatriation tax would be $T\left(\pi^{*}+\delta_{c}^{*}\right)=\left(\tau-\tau^{*}\right)\left(\pi^{*}+\delta_{c}^{*}\right)$, so that (10) becomes:

$$
\delta_{c}^{* m}\left(1-\tau^{*}\right)=(1-\tau) \delta_{c}+\left(\tau-\tau^{*}\right)\left(\pi^{*}+\delta_{c}^{* m}\right) \quad \Leftrightarrow \quad \delta_{c}^{* m} \gtrless \delta_{c}^{* N O}
$$

Under the tax credit system, some foreign acquisitions are carried out although national optimality would require domestic acquisitions, and vice versa. These results can be summarized as

Proposition 3 In the case of cost driven mÉa investment, the cross border cash flow tax system is nationally optimal. Under the full taxation after deduction system, foreign investment is inefficiently low. Under the tax credit system, over- and underinvestment coexist. The exemption system implies that foreign investment is unambiguously too high.

How about the ability of the different tax regimes to implement global optimality? In the case of cost driven greenfield investment, the tax credit system implements globally optimal investment. Does this result carry over to the case of m\&a investment? Under the tax credit system, the repatriation tax would be $T\left(\pi^{*}+\delta_{c}^{*}\right)=\left(\tau-\tau^{*}\right)\left(\pi^{*}+\delta_{c}^{*}\right)$. Using this expression in (10) leads to

$$
\delta_{c}^{* m}=\delta_{c}+\frac{\left(\tau-\tau^{*}\right)}{(1-\tau)} \pi^{*} \quad \Leftrightarrow \quad \delta_{c}^{* m}>\delta_{c}^{* G O} \quad \text { if } \tau>\tau^{*}
$$

It turns out that the global optimality of the tax credit system under cost driven greenfield investment also fails to carry over to the case of m\&a investment. Again, the repatriation tax imposes an undesirable burden on foreign acquisitions. Given that $\tau>\tau^{*}$, the tax credit system implies that the new owner is subject to a tax not faced by the initial owner. As a result, too few foreign acquisitions take place. How can global optimality be achieved? Rearranging (10) shows that the repatriation tax which would implement global optimality is given by

$$
T\left(\pi^{*}+\delta_{c}^{*}\right)=\left(\tau-\tau^{*}\right) \delta_{c}^{*}
$$

which is different from all four regimes introduced above. Essentially, the tax credit system has to be corrected for the inclusion of profits reflected in the 
purchase price. There is no easy way of implementing this because it would be difficult in practice to distinguish between hypothetical profits under the initial owner and profits generated due to the acquisition.

What are the implications of the remaining regimes for global optimality? The exemption system will lead to overinvestment in the low tax country, as in the case of greenfield investment. The full taxation after deduction system yields to underinvestment in the foreign country:

$$
\delta_{c}^{* m}=\delta_{c}+\tau\left[\delta_{c}^{*}+\pi^{*}\left(\frac{1-\tau^{*}}{1-\tau}\right)\right] \Leftrightarrow \delta_{c}^{* m}>\delta_{c}^{* G O}
$$

Finally, the cross border cash flow tax system, with $\tau\left(\left(\pi^{*}+\delta_{c}^{*}\right)\left(1-\tau^{*}\right)-q^{*}\right)$, leads to

$$
\delta_{c}^{* m}=\delta_{c}+\tau^{*} \delta_{c}^{*} \Leftrightarrow \delta_{c}^{* m}>\delta_{c}^{* G O}
$$

i.e. foreign investment is inefficiently low from a global perspective. This is not surprising, given the national optimality of this system in the case of m\&a investment. We may thus state

Proposition 4 In the case of cost driven m\&Ga investment, none of the four tax regimes under consideration leads to global optimality. The cross border cash flow tax system, the full taxation after deduction system and the tax credit system lead to underinvestment in the foreign country from a global point of view. The exemption system implies overinvestment in the high tax country and underinvestment in the low tax country.

Figure 2 summarizes the results for the case of cost driven m\&a investment. 


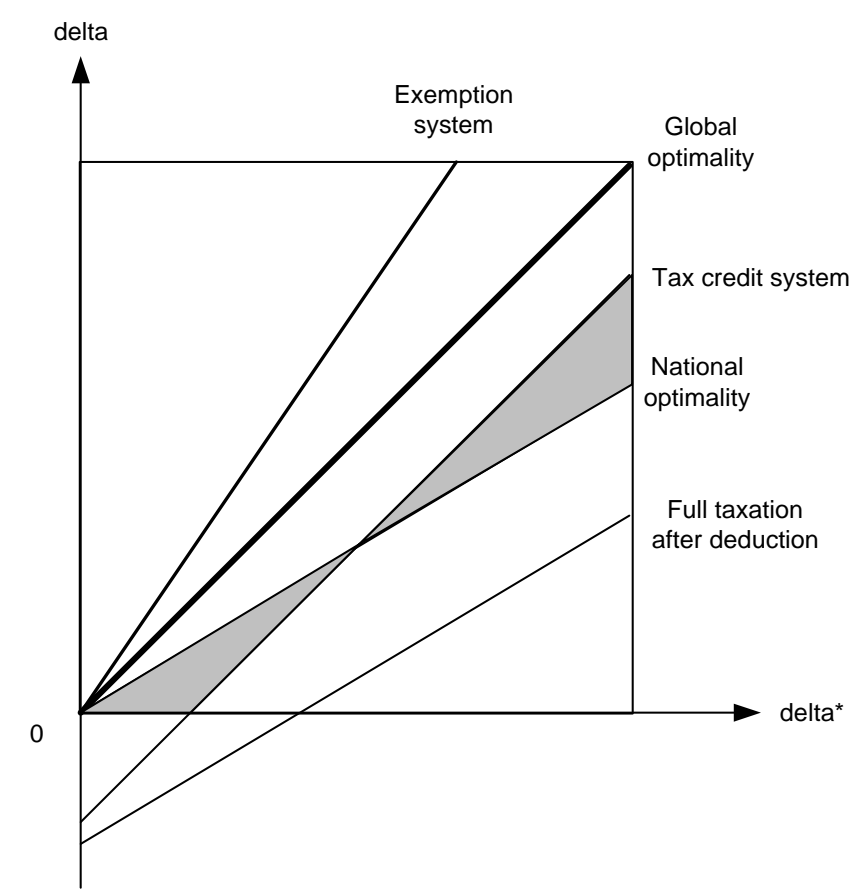

Figure 2: Cost driven m\&a investment

The 45 degree line describes the globally optimal margin at which $\delta_{c}^{* m}=\delta_{c}$. The exemption system leads to overinvestment abroad, as in figure 1 . The space between the exemption line and the global optimality line encompasses all projects which are carried out in the foreign country but which should be realized in the domestic country from a global optimality perspective. The remainder of the graph can be interpreted accordingly. The tax credit system and the full taxation after deduction system lead to foreign investment levels which are globally too low. The shaded areas characterize the interesting case of the tax credit system in which underinvestment and overinvestment coexist, seen from the national perspective.

\subsubsection{Market entry $m \& a$ investment}

Consider finally the case of market entry m\&a investment. The domestic investor firm now faces the choice between acquiring a target firm in the foreign country or not investing at all. The return of project $j$ is now denoted by $\delta_{e j}^{*}$. For each project, the representative investor firm draws a return $\delta_{e j}^{*}$ of a variable $\delta_{e}^{*} \in \mathbb{R}$ with density $\vartheta\left(\delta_{e}^{*}\right)$ and distribution $\Theta\left(\delta_{e}^{*}\right)$. Firms will carry out all projects in the 
foreign country with returns $\delta_{e j}^{*} \geq \delta_{e}^{m *}$, where the cutoff value $\delta_{e}^{m *}$ is given by

$$
\left(\pi^{*}+\delta_{e}^{m *}\right)\left(1-\tau^{*}\right)-T\left(\pi^{*}+\delta_{e}^{m *}\right)-q^{*}=0
$$

Using $q^{*}=\pi^{*}\left(1-\tau^{*}\right)$, it is straightforward to show that nationally optimal investment in the foreign country is given by

$$
\mathrm{NO}_{e}: \quad \delta_{e}^{N O *}\left(1-\tau^{*}\right)=0 \quad \Leftrightarrow \quad \delta_{e}^{N O *}=0
$$

National income increases with every project where the profit change caused by the acquisition after foreign taxes on these profits is positive. Comparing (22) and (23) shows that the nationally optimal tax on the marginal foreign investment project is equal to zero, i.e. $T\left(\pi^{*}+\delta_{e}^{m *}\right)=0$. There are again two regimes for taxing foreign profits which allow implementing this, the exemption system and the cross border cash flow tax system. The latter means $T\left(\pi^{*}+\delta_{e}^{*}\right)=\tau\left[\left(\pi^{*}+\right.\right.$ $\left.\delta_{e}^{*}\right)\left(1-\tau^{*}\right)-q^{*}$, which also implies $T\left(\pi^{*}+\delta_{e}^{m *}\right)=0$ but does tax intramarginal projects.

How do the tax credit system and the full taxation after deduction system perform with respect to national optimality? The tax credit system implies $T\left(\pi^{*}+\right.$ $\left.\delta_{e}^{*}\right)=\left(\tau-\tau^{*}\right)\left(\pi^{*}+\delta_{e}^{*}\right)$. Using this in (22) and making some rearrangements leads to

$$
\delta_{e}^{m *}(1-\tau)=\left(\tau-\tau^{*}\right) \pi^{*}>0 \quad \Leftrightarrow \quad \delta_{e}^{m *}>\delta_{e}^{N O *}
$$

The tax credit system yields too little foreign direct investment. Under the full taxation after deduction system, with $T\left(\pi^{*}+\delta_{e}^{*}\right)=\tau\left(\pi^{*}+\delta_{e}^{*}\right)\left(1-\tau^{*}\right)$, we also find that there is underinvestment in the foreign country:

$$
\delta_{e}^{m *}\left(1-\tau^{*}\right)=\frac{\tau}{1-\tau} \pi^{*}\left(1-\tau^{*}\right)>0 \quad \Leftrightarrow \quad \delta_{e}^{m *}>\delta_{e}^{N O *}
$$

How about global optimality? Here, the qualitative results are the same because global optimality also requires all projects with a positive return to the ownership change to be carried out, i.e.

$$
\mathrm{GO}_{e}: \quad \delta_{e}^{G O *}=0
$$


These findings may be summarized as

Proposition 5 In the case of market entry mÉa investment, the cross border cash flow tax system and the exemption system lead to both national and global optimality. The tax credit system and the full taxation after deduction system lead to too little investment abroad, both nationally and globally.

\section{Extensions}

The analysis in the preceding sections is based on a highly stylised model which uses several restrictive assumptions. In this section, we consider some extensions and variants of the model. These include i) the case where the supply of capital goods to the economy is inelastic, ii) the case where the initial owners of target firms may bargain with investor firms over the purchase price, and iii) the case where domestic and foreign investor firms compete for acquiring a given target firm.

\subsection{Inelastic supply of capital}

While we have assumed so far that the supply of capital to the economy is elastic, Feldstein and Hartman (1979) and many other contributions assume that the supply of capital is fixed. In this section, we briefly sketch the effects of introducing a fixed capital supply in our model. This only affects greenfield investment, and the results change primarily in the case of market entry greenfield investment. Due to a fixed capital supply, an increase in investment abroad would drive up the price per unit of capital $p$, so that investment at home c.p. declines.

This has two implications. First, nationally optimal investment again requires that the before tax return to domestic investment is equal to the return to foreign investment after foreign taxes. The deduction system makes sure that this condition holds. Global optimality requires equality of the before tax returns in both countries. This is achieved if the tax credit system is applied. Second, the price change may lead to a redistribution of income between capital owners and firm owners. If part of the capital stock is owned by foreigners, the domestic government may want to employ the tax system to reduce investment demand, so that 
the price of capital declines. If the entire capital stock is owned by domestic households, so that the equilibrium level of $p$ is irrelevant for overall national income, the deduction system is again nationally optimal.

In the case of cost driven greenfield investment, the number of projects which are carried out is given, so that overall capital demand is also given. The existence of an equilibrium requires the supply of capital supply to be at least as large as the number of investment projects. If this is not the case, the capital price will increase until the least profitable investment projects leave the market. But this will not change the results concerning the optimality properties of the tax regimes under consideration unless the choice of these regimes is influenced by the desire to change the equilibrum price of capital.

\subsection{Bargaining over the acquisition price}

So far, we have assumed that the initial owners of existing firms do not receive more than their reservation profit when they sell their firms. But in real world transactions, it is likely that they have some bargaining power so that they receive part of the surplus.

Consider firstly the case of cost driven m\&a. The surplus generated by a domestic (foreign) acquisition is given by $\delta_{c}(1-\tau)$ or $\delta_{c}^{*}\left(1-\tau^{*}\right)-T\left(\pi^{*}+\delta_{c}^{*}\right)$, respectively. Assume that the initial owners receive a share $0 \leq \beta \leq 1$ (or $0 \leq \beta^{*} \leq$ 1 ) of this surplus, so that the acquisition prices are $q=(1-\tau) \pi+\beta\left[\delta_{c}(1-\tau)\right]$ and $q^{*}=\pi^{*}\left(1-\tau^{*}\right)+\beta\left[\delta_{c}^{*}\left(1-\tau^{*}\right)-T\left(\pi^{*}+\delta_{c}^{*}\right)\right]$, respectively. ${ }^{16}$ Thus, the investor firm is indifferent between investing at home or abroad if

$$
\left(1-\beta^{*}\right)\left[\delta_{c}^{m *}\left(1-\tau^{*}\right)-T\left(\pi^{*}+\delta_{c}^{m *}\right)\right]=(1-\beta)\left[\delta_{c}(1-\tau)\right]
$$

If bargaining power is equal at home and abroad, $\left(\beta^{*}=\beta\right)$, the results derived in section 3 do not change, because the $\beta$ s drop out.

Now, consider the case of a market entry acquisition, where the reservation

\footnotetext{
${ }^{16}$ Here, we assume that the investor firm has to decide first whether to acquire the domestic or the foreign firm before negotiating, so that the reservation profit in the bargaining game is equal to zero. A more complicated setup would be one where bargaining with domestic and foreign initial owners takes place simultaneously.
} 
profit of the investor firm is equal to zero. The investor firm is indifferent between investing and not investing if

$$
(1-\beta)\left[\delta_{e}^{m *}\left(1-\tau^{*}\right)-T\left(\pi^{*}+\delta_{e}^{*}\right)\right]=0
$$

Again, the $\beta^{*}$ drops out.

The implications of the different tax regimes for global optimality are thus the same as those derived in the case with $q^{*}=\pi^{*}\left(1-\tau^{*}\right)$. As long as the domestic government takes the purchase price $q^{*}$ as given, the nationally optimal tax regime would also be the same: the cross border cash flow tax system in the case of cost driven $m \& a$ and the exemption system in the market entry m\&a case. But since the repatriation tax affects the purchase price, it will also affect the distribution of the surplus between the domestic and the foreign countries. The domestic government therefore has an incentive to use the repatriation tax in order to strategically manipulate the purchase price.

We do not analyze these strategic incentives further at this point, not only for reasons of space but also because they have to be seen in the context of the optimal tax rate choice. Including this would be beyond the scope of this paper.

\subsection{Domestic and foreign investor firms competing for ac- quisitions}

Another limitation of our analysis is that we have abstracted from the possibility that investor firms from different countries compete for the same target firm. Desai and Hines $(2003,2004)$ argue that US firms may be at a systematic disadvantage when competing for foreign acquisitions, and that this is against the national interest. Therefore assume that there is a second investor firm in the foreign country. The domestic and the foreign firm bid for a target firm located in the foreign country. In order to acquire the firm, the price the domestic firm offers has to be at least as high as the price offered by the foreign firm. The alternative to acquiring the firm is not to invest at all, i.e. we consider market entry investment. The change in profits which occurs if the foreign investor acquires the target firm is denoted by $\delta_{e}^{* f}$. The target firm will be acquired by the domestic investor in all 
cases where $\delta_{e}^{*} \geq \delta_{e}^{* m}$, where $\delta_{e}^{* m}$ is given by

$$
\left(\delta_{e}^{m *}+\pi^{*}\right)\left(1-\tau^{*}\right)-T\left(\pi^{*}+\delta_{e}^{m *}\right)=\left(\delta_{e}^{* f}+\pi^{*}\right)\left(1-\tau^{*}\right)
$$

which can be reduced to

$$
\delta_{e}^{m *}-\delta_{e}^{* f}=\frac{T\left(\pi^{*}+\delta_{e}^{m *}\right)}{\left(1-\tau^{*}\right)}
$$

It is immediately clear that any positive tax on foreign profits of a marginal project would imply too few foreign acquisitions of domestic investors from a global perspective. But is this also true from a national point of view? Nationally optimal investment implies that domestic firms should carry out the acquisition in all cases where

$$
\left(\delta_{e}^{*}+\pi^{*}\right)\left(1-\tau^{*}\right)-q^{*} \geq 0
$$

Using $q^{*}=\left(\delta_{e}^{* f}+\pi^{*}\right)\left(1-\tau^{*}\right)$, this can be reduced to

$$
\delta_{e}^{*}-\delta_{e}^{* f} \geq 0
$$

It turns out that nationally and globally optimal investment requires $T\left(\pi^{*}+\right.$ $\left.\delta_{e}^{m *}\right)=0$, which may be implemented either by using the exemption system or the cross border cash flow system. This confirms the results derived in the base version of the model and also the intuition in Desai and Hines (2003, 2004). It is straightforward to show that the results for the case of cost driven m\&a are also preserved if competition for acquisitions is taken into account.

\section{Discussion of the results and concluding re- marks}

In the preceding sections we have analyzed the effects of taxes on international capital flows when investment is m\&a rather than greenfield investment and market entry rather than cost driven investment. It has been shown that the tax effects may be quite different from the effects emerging in the standard capital mobility model. Table 2 briefly summarizes the results. 

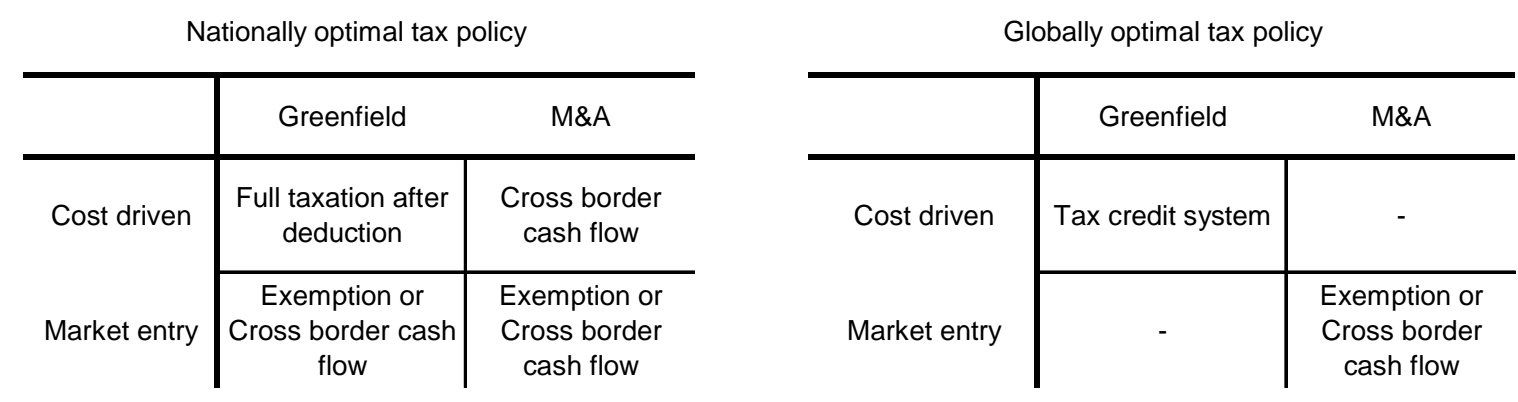

Table 2: Optimal tax policy strategies

What are the policy implications of the analysis? Firstly, the traditional focus on the tax credit system in double taxation agreements and European as well as international tax coordination proposals may be misguided. It is based on the assumption that the geographical location of investment matters for its productivity whereas corporate ownership structures do not. In the real world, however, corporate ownership structures are crucial for the exploitation of synergies, for access to technological and administrative know how and for the solution of corporate governance problems. In an increasingly knowledge based economy with declining communication and transport costs, these factors are likely to gain importance relative to the geographical location of production facilities. If this is correct, tax distortions of ownership structures deserve more attention.

Secondly, our results are relevant for the current debate in the U.S. and other countries on the way in which taxing foreign profits of domestic corporations affects national welfare. Our findings confirm the view expressed by Desai and Hines $(2003,2004)$ that the tax credit system may not be optimal in cases where acquiring foreign firms are not only in the interest of the firm but also in the national interest. Interestingly, the current tax policy debate in Germany points into the opposite direction. The fact that foreign profits are exempt from domestic taxes is often criticized because the exemption system is seen as creating incentives for German firms to invest abroad, where taxes are lower, rather than at home. A switch to a tax credit system is seen as beneficial for domestic economic activity. The results derived in this paper point to a neglected danger associated with such a move. Currently, Germany is the country of residence of many headquarters of multinational firms. Higher taxes on foreign profits of domestic firms would 
create incentives to sell foreign subsidiaries to multinational firms residing in other countries $^{17}$ although this is not in the national interest.

Thirdly, our results differ to what Desai and Hines (2003, 2004) suggest in two important aspects. In the case where investors decide whether to acquire a firm at home or abroad, the tax credit system does not necessarily imply that there are too few acquisitions from a national point of view; there may be too many as well. Moreover, the exemption system leads to overinvestment abroad. In this case, the cross border cash flow system is optimal from a national point of view. In addition, such a system has the same optimality properties as the exemption system when market entry investment is considered, see table $2 .{ }^{18}$

A fourth implication of our results is that neutrality of the tax system for all types of capital flows seems to be hard to achieve. The optimality properties, both from a national and a global point of view, crucially depend on the type of investment (greenfield or m\&a investment) and the model of investment (cost driven or market entry investment). Moreover, one should be aware that real world investment will always have both elements, greenfield investment and acquisition properties. Even in seemingly pure greenfield projects, investors typically have to acquire a piece of land which cannot be traded in world markets, so that the value of the land will be influenced by host country taxes.

Of course, these policy conclusions have to be seen in the light of the limitations of our analysis. The model used in this paper is highly stylized and neglects many aspects which are relevant for tax policy. A first extension would be to take into account that synergy effects can also emerge in the investor firm, see Becker \& Fuest (2006a). A second extension would be to consider a model where firms may choose between acquisitions and greenfield investment. Since the two may interact, the effects of tax policy on capital flows may be different from a world where only one of the two is taken into account. A third important aspect is that different ways of financing acquisitions and different forms of acquisitions - share deals versus asset deals, payments in cash or in shares of the parent company have

\footnotetext{
${ }^{17}$ Another option would be to move headquarters, a possibility not included in the analysis of this paper.

${ }^{18}$ Of course, the OECD double taxation convention does allow an exemption system whereas the possibility of introducing a cross border cash flow tax is not included. Therefore, the latter is no doubt more difficult to implement in practice.
} 
to be considered. Since tax credit systems usually imply that domestic taxes on foreign profits are deferred until repatriation, the tax effects on capital flows may be different if foreign investment is financed e.g. by retained earnings of foreign subsidiaries. A fourth very important aspect is imperfect competition. Many multinational firms operate in imperfectly competitive markets, and the interaction between different firms in these markets is an important factor driving m\&a. In such a framework, private and social benefits from mergers and acquisitions are likely to differ. Another question neglected in this paper is how capital flows in the form of m\&a affect optimal national tax policies in the presence of distortionary taxes and public goods provision. ${ }^{19}$ We intend to deal with these issues in future research.

\section{References}

Andrade, G., Mitchell, M. \& Stafford, E. (2001). New Evidence and Perspectives on Mergers, Journal of Economic Perspectives 15(2): 103-120.

Auerbach, A. J. \& Slemrod, J. (1997). The Economic Effects of the Tax Reform Act of 1986, Journal of Economic Literature 35(June): 12-13.

Becker, J. \& Fuest, C. (2006a). Quantity versus Quality - The Composition Effect of Corporate Taxation on Foreign Direct Investment, University of Cologne Working Paper .

Becker, J. \& Fuest, C. (2006b). Tax Competition and International Mergers and Acquisitions, University of Cologne Working Paper.

Bond, E. W. \& Samuelson, L. (1989). Strategic Behavior and the Rules for International Taxation of Capital, Economic Journal 99: 1099-1111.

Bucovetsky, S. \& Wilson, J. (1991). Tax Competition with Two Tax Instruments, Regional Science and Urban Economics 21: 333-350.

\footnotetext{
${ }^{19}$ In a companion paper (Becker \& Fuest (2006b)), we analyse tax competition and public goods provision in a model with M\&A.
} 
Collins, J., Kemsley, D. \& Shackelford, D. (1995). Tax Reform and Foreign Acquisitions: A Microanalysis, National Tax Journal 48(1): 1-21.

Desai, M. A. \& Hines, J. R. (2003). Evaluating International Tax Reform, National Tax Journal 56(3): 487-502.

Desai, M. A. \& Hines, J. R. (2004). Old Rules and New Realities: Corporate Tax Policy in a Global Setting, National Tax Journal 57(4): 937-60.

Desai, M. A. \& Hines, J. R. (2005). Old Rules and New Realities: Corporate Tax Policy in a Global Setting: Reply to Grubert, National Tax Journal 58(2): $275-278$.

Devereux, M. P. (1990). Capital Export Neutrality, Capital Import Neutrality, Capital Ownership Neutrality and All That, Unpublished Working Paper .

Devereux, M. P. (2006). The Impact of Taxation on the Location of Capital, Firms and Profit: A Survey of Empirical Evidence, Working Paper .

Devereux, M. P. \& Hubbard, R. G. (2003). Taxing Multinationals, International Tax and Public Finance 10(4): 469-87.

Di Giovanni, J. (2005). What Drives Capital Flows? The Case of Cross-Border Mergers and Acquisitions Activity and Financial Deepening, Journal of International Economics 65(1): 127-149.

Feldstein, M. \& Hartman, D. (1979). The Optimal Taxation of Foreign Source Investment Income, Quarterly Journal of Economics 93(4): 613-629.

Feldstein, M. \& Horioka, C. (1980). Domestic Saving and International Capital Flows, Economic Journal 90(358): 314-329.

Fuest, C. \& Huber, B. (2004). Why Do Countries Combine the Exemption System for the Taxation of Foreign Profits with Domestic Double Taxation Relief?, Journal of International Economics 62(1): 219-231.

Fuest, C., Huber, B. \& Mintz, J. (2005). Capital Mobility and Tax Competition, Foundations and Trends in Microeconomics 1(1): 1-62. 
Gordon, R. H. \& Bovenberg, A. L. (1996). Why is Capital So Immobile Internationally? Possible Explanations and Implications for Capital Income Taxation, American Economic Review 86: 1057-1075.

Grubert, H. (2005). Comment on Desai and Hines, "Old Rules and New Realities: Corporate Tax Policy in a Global Setting.", National Tax Journal 58(2): 263274.

Grubert, H. \& Mutti, J. (1995). Taxing Multinationals in a World with Portfolio Flows and R\&D - Is Capital Export Neutrality Obsolete?, International Tax and Public Finance 2(3): 439-457.

Haufler, A. \& Nielsen, S. B. (2005). Merger Policy to Promote Global Players? A Simple Model, CESifo Working Paper No. 1523.

Hines, J. R. (1999). Lessons from Behavioral Responses to International Taxation, National Tax Journal 52(2): 305-322.

Horst, T. (1980). A Note on the Optimal Taxation of International Investment Income, Quarterly Journal of Economics 94(4): 793-798.

Huck, S. \& Konrad, K. A. (2004). Merger Profitability and Trade Policy, Scandinavian Journal of Economics 106(1): 107-122.

Huizinga, H. \& Voget, J. (2005). International Taxation and the Direction and Volume of Cross-Border M\&As, Working Paper.

Janeba, E. (1995). Corporate Income Tax Competition, Double Taxation Treaties, and Foreign Direct Investment, Journal of Public Economics 56: 311-326.

Kaplan, S. (1989). Management Buyouts: Evidence on Taxes as a Source of Value, Journal of Finance 44(3): 611-632.

Keen, M. \& Piekkola, H. (1997). Simple Rules for the Optimal Taxation of International Capital Income, Scandinavian Journal of Economics 99(3): 447-461.

Markusen, J. R. (2002). Multinational Firms and the Theory of International Trade, Massachussets Institute of Technology, Cambridge, USA. 
McGuckin, R. \& Nguyen, S. (1995). On Productivity and Plant Ownership Change - New Evidence from the Longitudinal Research Database, Rand Journal of Economics 26(2): 257-276.

Mintz, J. \& Tulkens, H. (1996). Optimality Properties of Alternative Systems of Taxation of Foreign Capital Income, Journal of Public Economics 60: 373399.

Musgrave, P. B. (1969). United States Taxation of Foreign Investment Income: Issues and Arguments, Cambridge (MA), International Tax Program, Harvard Law School.

Rossi, S. \& Volpin, P. F. (2004). Cross-Country Determinants of Mergers and Acquisitions, Journal of Financial Economics 74(2): 277-304.

Schoar, A. (2002). Effects of Corporate Diversification on Productivity, Journal of Finance 57(6): 2379-2403.

Scholes, M. S. \& Wolfson, M. A. (1990). The Effects of Changes in Tax Laws on Corporate Reorganization Activity, Journal of Business 63(1): S141-164.

Swenson, D. L. (1994). The Impact of U.S. Tax Reform on Foreign Direct Investment in the United States, Journal of Public Economics 54(2): 243-266. 


\section{CESifo Working Paper Series}

(for full list see www.cesifo-group.de)

1824 J. Atsu Amegashie, A Psychological Game with Interdependent Preference Types, October 2006

1825 Kurt R. Brekke, Ingrid Koenigbauer and Odd Rune Straume, Reference Pricing of Pharmaceuticals, October 2006

1826 Sean Holly, M. Hashem Pesaran and Takashi Yamagata, A Spatio-Temporal Model of House Prices in the US, October 2006

1827 Margarita Katsimi and Thomas Moutos, Inequality and the US Import Demand Function, October 2006

1828 Eytan Sheshinski, Longevity and Aggregate Savings, October 2006

1829 Momi Dahan and Udi Nisan, Low Take-up Rates: The Role of Information, October 2006

1830 Dieter Urban, Multilateral Investment Agreement in a Political Equilibrium, October 2006

1831 Jan Bouckaert and Hans Degryse, Opt In Versus Opt Out: A Free-Entry Analysis of Privacy Policies, October 2006

1832 Wolfram F. Richter, Taxing Human Capital Efficiently: The Double Dividend of Taxing Non-qualified Labour more Heavily than Qualified Labour, October 2006

1833 Alberto Chong and Mark Gradstein, Who's Afraid of Foreign Aid? The Donors' Perspective, October 2006

1834 Dirk Schindler, Optimal Income Taxation with a Risky Asset - The Triple Income Tax, October 2006

1835 Andy Snell and Jonathan P. Thomas, Labour Contracts, Equal Treatment and WageUnemployment Dynamics, October 2006

1836 Peter Backé and Cezary Wójcik, Catching-up and Credit Booms in Central and Eastern European EU Member States and Acceding Countries: An Interpretation within the New Neoclassical Synthesis Framework, October 2006

1837 Lars P. Feld, Justina A.V. Fischer and Gebhard Kirchgaessner, The Effect of Direct Democracy on Income Redistribution: Evidence for Switzerland, October 2006

1838 Michael Rauscher, Voluntary Emission Reductions, Social Rewards, and Environmental Policy, November 2006 
1839 Vincent Vicard, Trade, Conflicts, and Political Integration: the Regional Interplays, November 2006

1840 Erkki Koskela and Mikko Puhakka, Stability and Dynamics in an Overlapping Generations Economy under Flexible Wage Negotiation and Capital Accumulation, November 2006

1841 Thiess Buettner, Michael Overesch, Ulrich Schreiber and Georg Wamser, Taxation and Capital Structure Choice - Evidence from a Panel of German Multinationals, November 2006

1842 Guglielmo Maria Caporale and Alexandros Kontonikas, The Euro and Inflation Uncertainty in the European Monetary Union, November 2006

1843 Jan K. Brueckner and Ann G. Largey, Social Interaction and Urban Sprawl, November 2006

1844 Eytan Sheshinski, Differentiated Annuities in a Pooling Equilibrium, November 2006

1845 Marc Suhrcke and Dieter Urban, Are Cardiovascular Diseases Bad for Economic Growth?, November 2006

1846 Sam Bucovetsky and Andreas Haufler, Preferential Tax Regimes with Asymmetric Countries, November 2006

1847 Luca Anderlini, Leonardo Felli and Andrew Postlewaite, Should Courts always Enforce what Contracting Parties Write?, November 2006

1848 Katharina Sailer, Searching the eBay Marketplace, November 2006

1849 Paul De Grauwe and Pablo Rovira Kaltwasser, A Behavioral Finance Model of the Exchange Rate with Many Forecasting Rules, November 2006

1850 Doina Maria Radulescu and Michael Stimmelmayr, ACE vs. CBIT: Which is Better for Investment and Welfare?, November 2006

1851 Guglielmo Maria Caporale and Mario Cerrato, Black Market and Official Exchange Rates: Long-Run Equilibrium and Short-Run Dynamics, November 2006

1852 Luca Anderlini, Leonardo Felli and Andrew Postlewaite, Active Courts and Menu Contracts, November 2006

1853 Andreas Haufler, Alexander Klemm and Guttorm Schjelderup, Economic Integration and Redistributive Taxation: A Simple Model with Ambiguous Results, November 2006

1854 S. Brock Blomberg, Thomas DeLeire and Gregory D. Hess, The (After) Life-Cycle Theory of Religious Contributions, November 2006 
1855 Albert Solé-Ollé and Pilar Sorribas-Navarro, The Effects of Partisan Alignment on the Allocation of Intergovernmental Transfers. Differences-in-Differences Estimates for Spain, November 2006

1856 Biswa N. Bhattacharyay, Understanding the Latest Wave and Future Shape of Regional Trade and Cooperation Agreements in Asia, November 2006

1857 Matz Dahlberg, Eva Mörk, Jørn Rattsø and Hanna Ågren, Using a Discontinuous Grant to Identify the Effect of Grants on Local Taxes and Spending, November 2006

1858 Ernesto Crivelli and Klaas Staal, Size and Soft Budget Constraints, November 2006

1859 Jens Brøchner, Jesper Jensen, Patrik Svensson and Peter Birch Sørensen, The Dilemmas of Tax Coordination in the Enlarged European Union, November 2006

1860 Marcel Gérard, Reforming the Taxation of Multijurisdictional Enterprises in Europe, "Coopetition" in a Bottom-up Federation, November 2006

1861 Frank Blasch and Alfons J. Weichenrieder, When Taxation Changes the Course of the Year - Fiscal Year Adjustments and the German Tax Reform 2000/2001, November 2006

1862 Hans Jarle Kind, Tore Nilssen and Lars Sørgard, Competition for Viewers and Advertisers in a TV Oligopoly, November 2006

1863 Bart Cockx, Stéphane Robin and Christian Goebel, Income Support Policies for PartTime Workers: A Stepping-Stone to Regular Jobs? An Application to Young LongTerm Unemployed Women in Belgium, December 2006

1864 Sascha O. Becker and Marc-Andreas Muendler, The Effect of FDI on Job Separation, December 2006

1865 Christos Kotsogiannis and Robert Schwager, Fiscal Equalization and Yardstick Competition, December 2006

1866 Mikael Carlsson, Stefan Eriksson and Nils Gottfries, Testing Theories of Job Creation: Does Supply Create Its Own Demand?, December 2006

1867 Jacques H. Drèze, Charles Figuières and Jean Hindriks, Voluntary Matching Grants Can Forestall Social Dumping, December 2006

1868 Thomas Eichner and Marco Runkel, Corporate Income Taxation of Multinationals and Unemployment, December 2006

1869 Balázs Égert, Central Bank Interventions, Communication and Interest Rate Policy in Emerging European Economies, December 2006

1870 John Geweke, Joel Horowitz and M. Hashem Pesaran, Econometrics: A Bird's Eye View, December 2006 
1871 Hans Jarle Kind, Marko Koethenbuerger and Guttorm Schjelderup, Taxation in TwoSided Markets, December 2006

1872 Hans Gersbach and Bernhard Pachl, Cake Division by Majority Decision, December 2006

1873 Gunther Schnabl, The Evolution of the East Asian Currency Baskets - Still Undisclosed and Changing, December 2006

1874 Horst Raff and Michael J. Ryan, Firm-Specific Characteristics and the Timing of Foreign Direct Investment Projects, December 2006

1875 Jukka Pirttilä and Håkan Selin, How Successful is the Dual Income Tax? Evidence from the Finnish Tax Reform of 1993, December 2006

1876 Agnieszka Stążka, Sources of Real Exchange Rate Fluctuations in Central and Eastern Europe - Temporary or Permanent?, December 2006

1877 Xavier Calsamiglia, Teresa Garcia-Milà and Therese J. McGuire, Why do Differences in the Degree of Fiscal Decentralization Endure?, December 2006

1878 Natacha Gilson, How to be Well Shod to Absorb Shocks? Shock Synchronization and Joining the Euro Zone, December 2006

1879 Scott Alan Carson, Modern Health Standards for Peoples of the Past: Biological Conditions by Race in the American South, 1873 - 1919, December 2006

1880 Peter Huber, Michael Pfaffermayr and Yvonne Wolfmayr, Are there Border Effects in the EU Wage Function?, December 2006

1881 Harry Flam and Håkan Nordström, Euro Effects on the Intensive and Extensive Margins of Trade, December 2006

1882 Panu Poutvaara and Mikael Priks, Hooliganism in the Shadow of the 9/11 Terrorist Attack and the Tsunami: Do Police Reduce Group Violence?, December 2006

1883 Ruud A. de Mooij and Gaëtan Nicodème, Corporate Tax Policy, Entrepreneurship and Incorporation in the EU, December 2006

1884 Johannes Becker and Clemens Fuest, Corporate Tax Policy and International Mergers and Acquisitions - Is the Tax Exemption System Superior?, January 2007 